natureresearch

Check for updates

\title{
OPEN Author Correction: Artificial Intelligence based Models for Screening of Hematologic Malignancies using Cell Population Data
}

\section{Shabbir Syed-Abdul, Rianda-Putra Firdani, Hee-Jung Chung, Mohy Uddin, Mina Hur, Jae Hyeon Park, Hyung Woo Kim, Anton Gradišek \& Erik Dovgan}

Correction to: Scientific Reports https://doi.org/10.1038/s41598-020-61247-0, published online 16 March 2020

This Article contains a typographical error in the Methods section where,

"We performed the hematologic analysis using Mindray BC-6800 (Mindray, Shenzhen, China) automated hematology analyzer that yielded CPD including CBC, leukocyte differentiation and reticulocyte count with information on volume, conductivity and different scatter measures ${ }^{23}$."

should read:

"We performed the hematologic analysis using Mindray BC-6800 plus (Mindray, Shenzhen, China) automated hematology analyzer that yielded CPD including CBC, leukocyte differentiation and reticulocyte count with information on volume, conductivity and different scatter measures ${ }^{23}$."

Also, the Article contains an error in Table 6 where the row entitled 'Ramdom Forest (RF)'.

should read:

'Random Forest (RF)'.

\begin{abstract}
(c) Open Access This article is licensed under a Creative Commons Attribution 4.0 International License, which permits use, sharing, adaptation, distribution and reproduction in any medium or format, as long as you give appropriate credit to the original author(s) and the source, provide a link to the Creative Commons license, and indicate if changes were made. The images or other third party material in this article are included in the article's Creative Commons license, unless indicated otherwise in a credit line to the material. If material is not included in the article's Creative Commons license and your intended use is not permitted by statutory regulation or exceeds the permitted use, you will need to obtain permission directly from the copyright holder. To view a copy of this license, visit http://creativecommons.org/licenses/by/4.0/.
\end{abstract}

(c) The Author(s) 2020 